\title{
Kernos
}

Revue internationale et pluridisciplinaire de religion grecque antique

8| 1995

Varia

\section{S. Ijsseling, Apollo, Dionysos, Aphrodite en de anderen. Griekse goden in de hedendaagse filosofie}

André Motte

\section{(2) OpenEdition}

Journals

Édition électronique

URL : http://journals.openedition.org/kernos/617

DOI : 10.4000/kernos. 617

ISSN : 2034-7871

Éditeur

Centre international d'étude de la religion grecque antique

Édition imprimée

Date de publication : 1 janvier 1995

Pagination : 309

ISSN : 0776-3824

Référence électronique

André Motte, «S. Ijsseling, Apollo, Dionysos, Aphrodite en de anderen. Griekse goden in de

hedendaagse filosofie », Kernos [En ligne], 8 | 1995, mis en ligne le 12 avril 2011, consulté le 24

septembre 2020. URL : http://journals.openedition.org/kernos/617 ; DOI : https://doi.org/10.4000/ kernos.617 
Samuel IJsseling, Apollo, Dionysos, Aphrodite en de anderen. Griekse goden in de bedendaagse filosofie, Amsterdam, Boom, 1994, 1 vol. 12, $5 \mathrm{x}$ $20 \mathrm{~cm}, 197$ p. ISBN : 90- $5352-120-8$.

On savait les Anciens de retour ${ }^{14}$ et les penseurs modernes toujours prompts à se réclamer d'eux sous le couvert des stratégies les plus diverses. Mais savait-on qu'il est possible encore, en ressuscitant des figures divines ou héroïques qui peuplent les vieux grimoires de la religion et de la mythologie grecques, d'entrer en dialogue avec les Nietzsche, Husserl, Heidegger, Bataille, Foucault, Lacan, Levinas, Derrida, Lyotard et quelques autres, et de proposer ainsi une introduction à l'étude de la philosophie contemporaine ? Tel est le défi que tente de relever l'A., professeur d'histoire de la philosophie moderne et contemporaine à la Katholieke Universiteit Leuven. La couverture du livre reproduit l'image de l'«Athéna pensive » du Musée de l'Acropole d'Athènes, en écho à la reproduction qu'Heidegger tenait sous le regard dans son bureau de Fribourg. Clin d'œil au film de Claude Sautet, le titre indique à suffisance qu'on ne doit pas s'attendre à une présentation savante et systématique des divinités du panthéon, mais à une libre randonnée à travers leurs mythes «fascinants » et qu'il n'est qu'une manière de comprendre en profondeur : les raconter à nouveau. L'A. ne le fait pas en dilettante; sachant puiser son information aux meilleures sources de l'exégèse actuelle (Vernant, Detienne, Veyne, etc.), il montre comment sont présentes dans certains récits anciens des questions qui n'ont cessé depuis Nietzsche d'agiter la pensée philosophique contemporaine. L'énoncé, en traduction, de quelques titres donnés aux douze chapitres qui composent l'ouvrage donnera une idée de cet intéressant parcours dans lequel les hellénistes aussi trouveront matière à une utile réflexion : "Le dionysiaque et la déconstruction", "Admète, Alceste et la mort ", "Thésée, Ariane et l'oubli », "Hélène et les sophistes ", "Prométhée, la technique, le feu et l'holocauste ", "Le polythéisme et les postmodernes ». Un essai intelligent, dont on doit souhaiter une prochaine traduction.

A. MOTTE

(Université de Liège)

Marie-Odile Jentel, Euthénia. Corpus des monuments et étude iconograpbique, Québec, Presses de l'Université Laval, 1993. 1 vol. $21,5 \times 27 \mathrm{~cm}$, 254 p., 150 fig. (Coll. Hier pour aujourd'bui, 5).

Euthénia, connue presque seulement en Égypte, est souvent considérée comme une figure allégorique de second ordre, liée au dieu Nil, dont on fait

14 Cf. G. CAMBIANo, Le retour des Anctens, traduit de l'italien par Silvia Melanezi, préface de Nicole Loraux, Paris, Belin, 1994. Cf, aussi : B. CASSIN (éd.), Nos Grecs et leurs modernes, Paris, Seuil, 1992; R.-P. DROIT (éd.), Les Grecs, les Romains et nous. L'Antiquité est-elle moderne ?, Paris, Le Monde Éditions, 1991; le premier numéro de la revue Descartes, organe du Collège international de philosophie (Paris, Albin Michel, 1991), est intitulé Des Grecs. 